\title{
Metastatic Disease Indicator
}

National Cancer Institute

\section{Source}

National Cancer Institute. Metastatic Disease Indicator. NCI Thesaurus. Code C132456.

An indication as to whether a malignancy has appeared at sites distant to the primary site of disease. 